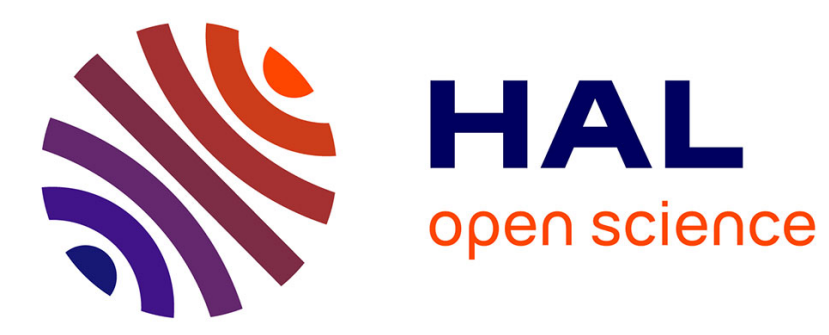

\title{
Carbon stock changes of forest land in Finland under different levels of wood use and climate change
}

Risto Sievänen, Olli Salminen, Aleksi Lehtonen, Paavo Ojanen, Jari Liski, Kimmo Ruosteenoja, Mikko Tuomi

\section{- To cite this version:}

Risto Sievänen, Olli Salminen, Aleksi Lehtonen, Paavo Ojanen, Jari Liski, et al.. Carbon stock changes of forest land in Finland under different levels of wood use and climate change. Annals of Forest Science, 2014, 71 (2), pp.255-265. 10.1007/s13595-013-0295-7 . hal-01098410

\section{HAL Id: hal-01098410 https://hal.science/hal-01098410}

Submitted on 24 Dec 2014

HAL is a multi-disciplinary open access archive for the deposit and dissemination of scientific research documents, whether they are published or not. The documents may come from teaching and research institutions in France or abroad, or from public or private research centers.
L'archive ouverte pluridisciplinaire HAL, est destinée au dépôt et à la diffusion de documents scientifiques de niveau recherche, publiés ou non, émanant des établissements d'enseignement et de recherche français ou étrangers, des laboratoires publics ou privés. 


\title{
Carbon stock changes of forest land in Finland under different levels of wood use and climate change
}

\author{
Risto Sievänen • Olli Salminen • Aleksi Lehtonen • \\ Paavo Ojanen • Jari Liski • Kimmo Ruosteenoja • \\ Mikko Tuomi
}

Received: 26 November 2012 / Accepted: 1 May 2013 /Published online: 22 May 2013

(C) INRA and Springer-Verlag France 2013

\begin{abstract}
- Context Prediction of the effect of harvests and climate change (CC) on the changes in carbon stock of forests is necessary both for $\mathrm{CC}$ mitigation and adaptation purposes.

- Aims We assessed the impact of roundwood and fuelwood removals and climate change (CC) on the changes in carbon stock of Finnish forests during 2007-2042. We considered three harvest scenarios: two based on the recent projections of roundwood and fuelwood demand, and the third reflecting the maximum sustainable cutting level. We applied two climate scenarios: the climate was in the state that prevailed around year 2006, or it changed according to the IPCC SRES A1B scenario.

- Methods We combined the large-scale forestry model MELA with the soil carbon model Yasso07 for mineral soils.
\end{abstract}

\begin{abstract}
Handling Editor: Erwin Dreyer
Contributions of the co-authors R. Sievänen was the responsible author; all other authors provided text and commented the MS for improvements. R. Sievänen made the carbon balance calculations, O. Salminen produced tree stock data with the MELA system, A.

Lehtonen provided program modules for biomass and litter production calculations, P. Ojanen provided the component for calculating emissions of organics soils, K. Ruosteenoja provided the data for climate change scenarios, and J. Liski and M. Tuomi provided the Yasso07 model for mineral soils.
\end{abstract}

\footnotetext{
R. Sievänen $(\bowtie) \cdot$ O. Salminen $\cdot$ A. Lehtonen

Finnish Forest Research Institute, Jokiniemenkuja 1,

Box 18, 01301 Vantaa, Finland

e-mail: risto.sievanen@metla.fi

P. Ojanen

Department of Forest Sciences, University of Helsinki,

Helsinki, Finland

J. Liski $\cdot$ M. Tuomi

Finnish Environment Institute, Helsinki, Finland

K. Ruosteenoja

Finnish Meteorological Institute, Helsinki, Finland
}

For soils of drained, forested peatlands, we used a method based on emission factors.

- Results The stock change of trees accounted for approximately $80 \%$ of the total stock change. Trees and mineral soils acted as carbon sinks and the drained peatland soils as a carbon source. The forest carbon sink increased clearly in both of the demand-based scenarios, reaching the level of 13-20 Tg C/year (without CC). The planned increase in the use of bioenergy reduced the forest sink by $2.6 \mathrm{Tg} \mathrm{C} / \mathrm{year}$. CC increased the forest carbon sink in 2042 by $38 \%-58 \%$ depending on the scenario. CC decreased the sink of mineral soils in the initial years of the simulations; after 2030, the effect was slightly positive. CC increased the emissions from the drained peatland soils.

- Conclusions It is likely that forest land in Finland acts as a carbon sink in the future. The changes in carbon stocks of trees, mineral soils, and peatland soils respond differently to $\mathrm{CC}$ and fuelwood and roundwood harvests.

Keywords Carbon dioxide $\cdot$ Modeling $\cdot$ Forest sink . Roundwood removal $\cdot$ Bioenergy $\cdot$ Climate change $\cdot$ Finland

\section{Introduction}

The forests of Finland provide a considerable amount of roundwood for industrial use each year, and in the last decade, the average amount was $53 \mathrm{Mm}^{3}$. In spite of this level of timber offtake, growth has exceeded harvest by more than $20 \%$ over the last 30 years. During the same period, the annual increment has increased nearly $52 \%$ and is now $103.7 \mathrm{Mm}^{3}$ (Finnish Statistical Yearbook of Forestry 2011). It is anticipated that the reshaping of traditional forest industries will cause a $30 \%$ decline in the industrial use of roundwood over the period 2007 to 2020 (Hetemäki and Hänninen 2009). However, the use of biomass for bioenergy is rapidly increasing, and the government has established a 
target of increasing it from the current annual level of $7 \mathrm{Mm}^{3}$ up to $13.5 \mathrm{Mm}^{3}$ by 2020 (Ministry of Employment and the Economy 2010).

Climate models project that temperature and precipitation will increase in Scandinavia (Jylhä et al. 2009), and such climate change (CC) will increase forest growth (Kellomäki et al. 2008). However, it will also increase the rate of decomposition of organic matter, which may considerably affect the changes in carbon stock of forest soils (Kirschbaum 1995). The proportion of peatland forests is relatively high in Finland; almost a quarter of the total forest area is peatland forest. The carbon pool in peat is substantial (Turunen 2008), and carbon emissions from peat soils are sensitive to $\mathrm{CC}$ because of the effects of temperature and the effects of the groundwater table (Ojanen et al. 2013).

The level of wood harvest and CC are the main factors that influence the dynamics of growth and the carbon stock of the Finnish forests (Matala et al. 2009). It is necessary to assess the future growing stock and changes in carbon stock of forests for many purposes, e.g., for planning climate and forestry policy. Projections of greenhouse gas emissions, including the contribution of forests, are required as a part of the National Communications under the United Nations Framework Convention on Climate Change. There are a large number of national and regional studies concerning the changes in carbon stock of forests, e.g., those by Werner et al. (2010), Peckham et al. (2012), Matala et al. (2009), Thürig and Kaufmann (2010), Poudel et al. (2011, 2012), Cienciela et al. (2008), Karjalainen et al. 2002, and Pingoud and Lehtilä (1997). In addition, projections have been made for the entire EU (Böttcher et al. 2012).

The system boundaries and the inputs in the calculations varied in these studies. Peckham et al. (2012), Poudel et al. (2011, 2012), Pingoud and Lehtilä (1997), and Werner et al. (2010) considered, in addition, the wood products and the effects of the reduction of emissions from the use of wood products on the changes in carbon stock of forests. Poudel et al. (2011), Cienciala et al. (2008), Karjalainen et al. (2002), and Matala et al. (2009) simulated the effects of CC.

In these studies, the amounts of future harvests were taken to be at some plausible levels (e.g., current or maximum), or various forest management options (e.g., promoting biomass production or favoring short rotation periods) were applied that influenced the amount of the harvests. Another approach was to maximize a criterion, such as carbon uptake (Peckham et al. 2012) or stocks of biomass (Poudel et al. 2012), and observe the harvest levels resulting from the optimization. However, it can be argued that the demand for wood and biomass by forest industries and other consumers sets the framework in which the effects of the various management options should be assessed. Of the vast number of possible forest management alternatives, only those that yield harvests that satisfy the projected demand for wood are interesting from the standpoint of projecting future carbon stocks. Only the studies of Böttcher et al. (2012) and Pingoud and Lehtilä (1997) derived the harvests from wood demand scenarios.

Most of the studies referred to above concerned changes in total carbon stock (biomass and soil combined). Only Cienciela et al. (2008) and Thürig and Kaufmann (2010) considered biomass and soil separately. Biomass and soil carbon pools may react differently to both $\mathrm{CC}$ and forest management activity (Kirschbaum, 1995). The separate consideration of the various carbon pools by Cienciela et al. (2008) and Thürig and Kaufmann (2010) thus gave a more comprehensive picture of the development of forest carbon stock.

In the present study, we combine the scenarios of wood demand and CC and assess the development of carbon stock of forests in Finland. We present scenarios for the years 2007-2042. The scenarios of wood demand consider roundwood demand by the forest industry and fuelwood usage that result from the targets set in the energy policy. We apply two options for $\mathrm{CC}$ scenarios: no change and change according to the IPCC SRES A1B scenario. We consider the three main pools of carbon separately: trees, mineral forest soils, and drained peatland forest soils.

\section{Materials and methods}

\subsection{General structure of the calculation system}

To assess the changes in carbon stock of Finnish forests, we combined three models (Fig. 1): the large-scale forestry model MELA (version MELA2009, Redsven et al. 2011), the soil carbon model Yasso07 (Tuomi et al. 2011) for mineral soils, and a method based on emission factors for peatland soils (see below, "Changes in carbon stock of forested, drained peatland soils"). We included the entire forested area of Finland, a total of 20.8 Mha. Most of that area, ca. $82 \%$, is managed for commercial forestry, and the rest is partially or totally protected. Forested and drained peatlands comprise almost one fourth of the area, 4.7 Mha.

We estimated the changes in carbon stocks of trees and soil using a methodology similar to that applied in the Finnish Greenhouse Gas Inventory (FGHGI), which is explained in detail in the National Inventory Report (NIR 2012) (Greenhouse gas emissions in Finland 1990-2010). There were two differences in our calculations compared to NIR2012. First, the FGHGI uses data from the National Forest Inventory (NFI) instead of model outputs (cf. Fig. 1). Second, the FGHGI estimates the change in dead wood stock based on measurements; in our case, dead wood was included in the change of soil carbon stock, similar to other regional applications of the Yasso model (e.g., Liski et al. 2006). 


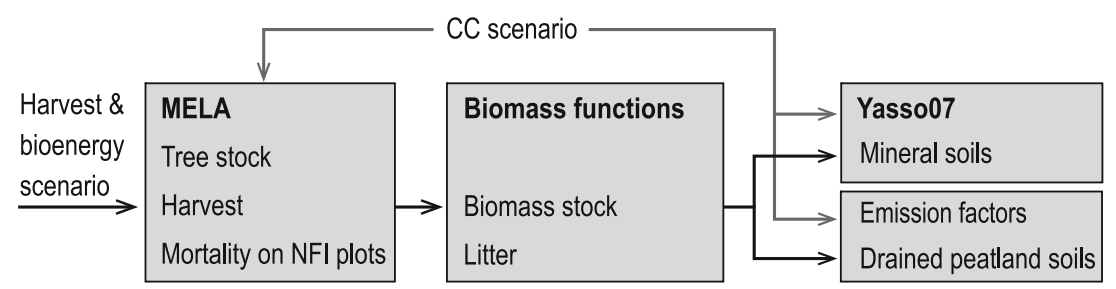

Fig. 1 The structure of the calculation system for the changes in carbon stocks of trees, mineral soils, and drained peatland soils for the scenario analyses. Harvest and bioenergy scenarios are given as constraints (specified amounts of roundwood and fuelwood removal)

The FGHGI estimates the change in soil stock separately for Southern and Northern Finland, using different weather data. The border between the two areas lies approximately at latitude $63.7^{\circ} \mathrm{N}$ (Finland is approximately between latitudes $60^{\circ} \mathrm{N}$ and $70^{\circ} \mathrm{N}$ ). We used the same division for our calculations.

\subsection{Prediction of forest growth and dynamics of tree stock}

MELA (Siitonen et al. 1996) is a forestry model and an operational decision support system for tasks of forest management planning such as (1) determining the production potentials of forests and (2) managing forest stands in a region (across Finland or in a specified subregion) to achieve the overall goals set for forestry. The MELA program has been used regularly to project forest resources for policy making, e.g., for the Finnish national forestry programs (Salminen and Hirvelä 2008). MELA consists of a stand simulator and an optimization tool based on linear programming (JLP, Lappi 1992). The simulator is based on automated event simulations and on tree-level empirical models that simulate growth, mortality, and in-growth of trees (e.g., Hynynen et al. 2002).

The growth models have been calibrated so that they account for the growth of forests as for the decade 1999-2008. MELA contains a module that predicts the change in the growth rate as a function of the increase in annual mean temperature or ambient $\mathrm{CO}_{2}$ concentration (Matala et al. 2005) (Fig. 2a). Several authors, such as Nuutinen et al. (2006) and Matala et al. (2009), have used this module to assess changes in forest production under CC. In our analysis, the changes in $\mathrm{CO}_{2}$ and annual mean temperature relative to the values for 2006 were fed into MELA to calculate the changes in growth and determine the optimal forest management.

We used information from the 10th NFI, measured in 2004-2008, as the input data for our MELA analysis. We used MELA to simulate a number of feasible actions for each management unit. The simulated alternatives of fuelwood harvesting were the following: (1) collecting logging residues (branches and tops or branches, tops, and stumps) from traditional commercial roundwood cuts and (2) applying whole-tree or trunk-felling methods during thinning that was either integrated with roundwood harvest or done as an to the MELA program. Data from the National Forest Inventory (NFI) plots are used to initialize the predictions of the development of tree stock. The climate change (CC) scenario specifies the annual mean temperature, precipitation, and ambient $\mathrm{CO}_{2}$ concentration

independent logging for fuelwood. The effect of nutrient loss on the growth of young stands due to whole-tree harvest is taken into account; growth rate is lower after the harvest according to the results of Helmisaari et al. (2011).

\subsection{Changes in carbon stock of trees}

We transformed the stem volumes from MELA to biomass compartments using the biomass expansion factors (BEFs) from NIR2012. We calculated the changes in carbon stock of the trees simply as the difference in carbon stocks between two consecutive years. The output interval of MELA was 10 years, and thus, the stock change is constant between the output years. We assigned this value to the middle years of the intervals and interpolated linearly between them.

\subsection{Simulation of litter production}

The annual litter input into the soil originates from living trees, harvest residues, unrecovered natural mortality of trees, and from the ground vegetation. Annual litter production from compartments of a living tree is proportional to their biomass

We applied the BEFs (NIR2012) to the stem volume of dead trees that were predicted by MELA to account for the litter from unrecovered natural mortality. The amount of litter from harvest residues was calculated by MELA using treewise biomass functions (Repola 2008, 2009).

The annual litter input from understory vegetation was constant for mineral and peatland soils and was the same as in the NIR2012. The litter input on mineral soils was $0.51 \mathrm{t} \mathrm{C} / \mathrm{ha}$ and $0.67 \mathrm{t} \mathrm{C} / \mathrm{ha}$ in Southern and Northern Finland, respectively. Due to the lack of region-specific data (cf. NIR2012) for the below-ground litter input from understory vegetation in peatland forests, a constant value of $1.11 \mathrm{t} \mathrm{C} /$ ha was used throughout the country.

\subsection{Changes in carbon stock of mineral soils}

We used Yasso07 (Tuomi et al. 2011) to calculate the changes in the carbon stock of mineral soils in the same way that Yasso07 and its earlier versions have been used in studies on the regional level (e.g., Karjalainen et al. 2002, 

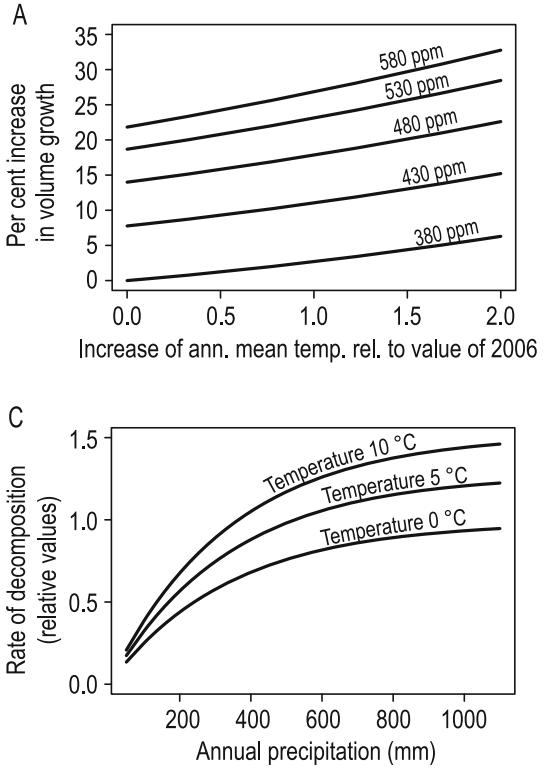

Fig. 2 The sensitivity of model calculations to changes in climate variables. a The increase in volume growth of a Scots pine tree growing under moderate competition in a medium dense stand in MELA. Growth is presented as a function of the increase of mean annual temperature relative to the value of year 2006 at different levels of ambient $\mathrm{CO}_{2}$ concentration. The effects of annual mean temperature and ambient $\mathrm{CO}_{2}$ concentration on tree growth depend on the tree

Liski et al. 2006, Cienciela et al. 2008, Thürig and Kaufmann 2010, and Rantakari et al. 2012). The annual litter production forms the input of carbon to Yasso07, and the model estimates the size of the carbon stock and its annual change.

The annual mean temperature, the difference between the mean temperatures of the warmest and coldest months of the year, and the amount of precipitation are the climate input to Yasso07 (Tuomi et al. 2011). The decomposition of organic matter in Yasso07 increases with increasing mean annual temperature and precipitation (see Figs. $2 \mathrm{~b}$ and $\mathrm{c}$ ). The parameter values of Yasso07 were according to (Rantakari et al. 2012).

In addition to litter input and climatic data input, Yasso07 simulations require initial values of carbon stocks. We ran Yasso07 from 1971 to 2006 in the same way and with the same litter input as in the FGHGI to determine the simulated carbon stock values for 2006 . We then decreased these stock values by $10 \%$ to account for the different litter input from MELA in 2007 than from the FGHGI and used these as initial values for the carbon stocks.

2.6 Changes in carbon stock of forested, drained peatland soils

We calculated the changes in carbon stock of forested, drained peatland soils as was done for the FGHGI (NIR2012). The

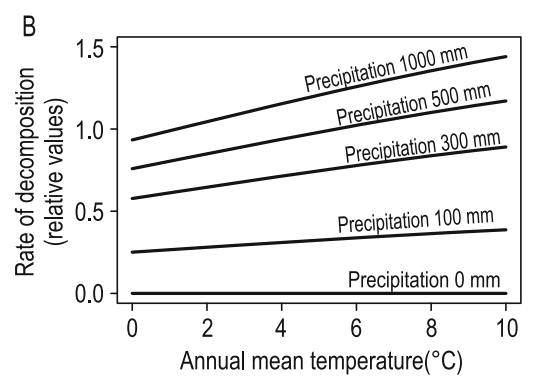

species, the stand density, and the social status of the tree (Matala et al. 2005). The graphs in (a) indicate the general shape of the climate sensitivity of growth. b, $\mathbf{c}$ The rate of decomposition of organic matter in Yasso07 (Tuomi et al. 2009) with respect to annual mean temperature (b; with different levels of annual precipitation) and precipitation (c; at different annual mean temperatures)

stock change is the difference between the input of dead organic matter into the soil and the decomposition of soil organic matter (SOM):

\section{change in SOM}

$=$ below-ground litter input-emission from soil

In this calculation, it is assumed that the above-ground litter pool is at a steady state. The emission from soil depends on the peatland type. The emissions from various types of peatland were calculated as (area estimate of type $) \times($ type-specific emission factor) (NIR2012).

The site-type-specific emission factors have been determined experimentally (Minkkinen et al. 2007) and are used as constants in the FGHGI (NIR2012). Further studies (Ojanen et al. 2010) have shown that they depend on temperature and the stem volume of the stand. On the basis of Ojanen et al. (2010), if either the mean May-October temperature $\left(T,{ }^{\circ} \mathrm{C}\right)$ or mean stem volume of forested peatlands $\left(V, \mathrm{~m}^{3} / \mathrm{ha}\right)$ changed from the 2006 values, the emission factor, $e\left(\mathrm{~g} \mathrm{CO}_{2} \mathrm{~m}^{-2}\right.$ year $\left.{ }^{-1}\right)$, changed in proportion to the difference between the value and the 2006 value (subscript 2006):

$e=e_{0}+0.833\left(V-V_{2006}\right)+135\left(T-T_{2006}\right)$

where $e_{0}$ is the emission factor reported by Minkkinen et al. (2007). Equation 1 implies that every $1{ }^{\circ} \mathrm{C}$ rise in mean 
May-October temperature increases the emissions by $13.0 \%$ and that a change of $1 \mathrm{~m}^{3} /$ ha of mean stem volume increases the emissions by $0.08 \%$. We approximated the change in the mean May-October temperature using the change of annual mean temperature $T_{\mathrm{m}}$ as

$T-T_{2006}=0.7\left(T_{\mathrm{m}}-T_{\mathrm{m} 2006}\right)$

on the basis of a comparison of temperature responses in simulations performed with 19 global climate models for the period 2013-2050 (Jylhä et al. 2009).

\subsection{Commercial cutting and bioenergy scenarios}

The scenarios extend from 2007 to 2042. The capacity of the Finnish paper and pulp industry has declined in recent years due to the reduced demand for wood products in Europe and in the northern hemisphere. This trend is expected to continue in the future in the two studies that we used for industrial wood use: Hetemäki and Hänninen (2009) predict a lower industrial use of wood than a study by the Ministry of Employment and the Economy (MEE) (Kärhä et al. 2010). In addition to the domestic harvest, import of roundwood satisfies part of the industrial need for wood. The exports of roundwood and fuelwood have been very low in Finland. We assumed that these conditions will continue to prevail. We used the prediction by Hetemäki and Hänninen (2009) with the assumption of relatively high annual imports of roundwood $\left(7.8 \mathrm{Mm}^{3}\right)$ for the low commercial harvest scenario (LOW, Table 1). For the moderate alternative scenario (MOD, Table 1), we used the MEE prediction and a low annual import of roundwood $\left(2.8 \mathrm{Mm}^{3}\right)$. As the third alternative (POT, Table 1), we simulated cuttings at the maximum sustainable harvest level. Here, "sustainable" means that the amount of harvest will not decrease in the future. This alternative is not based on any analysis of future wood usage; it rather reflects the potential wood supply level of the Finnish forests. The scenarios of Hetemäki and Hänninen (2009) and MEE

Table 1 Roundwood and fuel wood removal in 2020 according to different scenarios

\begin{tabular}{lll}
\hline Scenario & $\begin{array}{l}\text { Roundwood removal } \\
\text { in } 2020\left(\mathrm{Mm}^{3}\right)\end{array}$ & $\begin{array}{l}\text { Fuel wood removal } \\
\text { in } 2020\left(\mathrm{Mm}^{3}\right)\end{array}$ \\
\hline LOW\&BIO- & 43.9 & 18.0 \\
MOD\&BIO- & 56.6 & 18.0 \\
LOW\&BIO+ & 43.9 & 25.5 \\
MOD\&BIO+ & 56.6 & 25.5 \\
POT & 74.8 & 24.0 \\
\hline
\end{tabular}

The low, moderate, and high use of wood are presented by scenarios LOW\&BIO-, MOD\&BIO+, and POT, respectively. The LOW\&BIO+ and MOD\&BIO+ scenarios contribute to assessing the effect of fuel wood removal on carbon stocks extend only to 2020. We assumed that industrial cuttings will remain at 2020 levels after that. Under the POT scenario, the high rate of harvest commenced immediately. The harvest levels of the three alternatives are shown in Table 1.

The Finnish Climate and Energy Strategy adopted in 2010 set a target to increase the use of wood chips to $13.5 \mathrm{Mm}^{3}$ per year by 2020 , which means almost doubling the current level of use $\left(7 \mathrm{Mm}^{3}\right.$ in 2010). In addition, there are plans to promote biofuel production from woody biomass that may, in a favorable case, increase the consumption of forest chips by $6.5 \mathrm{Mm}^{3}$ per year in 2020 . In that case, there would be three large biorefineries making biodiesel. We defined meeting these targets as the high bioenergy scenario. The bioenergy demand increases gradually from 2007 to 2020 and then remains unchanged. For the low bioenergy alternative, we assumed that the wood chip target would not be reached and that the consumption of forest chips is $6.5 \mathrm{Mm}^{3}$ in 2020 . Additionally, the consumption of wood for biofuels is a bit lower, at $6.0 \mathrm{Mm}^{3}$ per year. In addition to these, $5.5 \mathrm{Mm}^{3}$ of wood is used for heating in small-scale housing. We assumed that this remains unchanged under the $\mathrm{BIO}+$ and $\mathrm{BIO}-$ scenarios. Accordingly, the total consumption per year in 2020 is $25.5 \mathrm{Mm}^{3}$ and $18 \mathrm{Mm}^{3}$ under the $\mathrm{BIO}+$ and $\mathrm{BIO}-$ scenarios, respectively (Table 1). Furthermore, we assumed that the current subsidies for fuelwood logging and chipping from young stands will continue under the $\mathrm{BIO}+$ but not in the $\mathrm{BIO}-$ scenario.

Under the POT scenario, there were no explicit targets for bioenergy production, but the bioenergy harvest was maintained through time. Subsidies for young stand fuelwood logging were also used for this scenario. The fuelwood removal was almost equal to that under the $\mathrm{BIO}+$ scenario (Table 1).

\subsection{Climate change scenarios}

We consider two scenarios for the future climate. In the first alternative (no change), the effect of $\mathrm{CC}$ was not considered either in MELA or in the emission factors for soil in peatland forests $\left(T-T_{2006}=0\right.$ in Eq. 1). Yasso07 was run with the average annual mean temperature and precipitation values of the period 2002-2006. The values for Northern and Southern Finland were, respectively, $1.09{ }^{\circ} \mathrm{C}$ and $4.26{ }^{\circ} \mathrm{C}$ for the annual mean temperature and $522 \mathrm{~mm}$ and $567 \mathrm{~mm}$ for precipitation. For the difference between the mean temperatures of the warmest and coldest month of the year, we used mean values from the period 1981-2010, which Yasso07 uses as input. The values are $14.5^{\circ} \mathrm{C}$ and $13.2{ }^{\circ} \mathrm{C}$ in Northern and Southern Finland, respectively (K. Jylhä, personal communication 2012).

In the second alternative (A1B), we assumed that the ambient $\mathrm{CO}_{2}$ concentration, annual mean temperature, and 
precipitation changed according to the IPCC SRES A1B scenario. The temperature and precipitation projections were calculated as the mean of the simulations performed with 19 global climate models (Jylhä et al. 2009). The time series of the temperature and precipitation change, averaged over the southern and northern parts of the country, are given in Fig. 3. These time series were used in the Yasso07 calculations to increase the annual mean temperature and precipitation and for calculating the emission factors of peatland forest soils (Eq. 1). We ignored the small decrease in the difference in mean temperatures between the coldest and warmest month of the years during the period 2007-2042.

In the MELA calculations, we employed the A1B CC scenario at 16 locations throughout Finland for the annual mean temperature and ambient $\mathrm{CO}_{2}$ concentration. MELA uses these values to calculate changes in the growth rate of trees (cf. Fig 3a).

\subsection{Growing stock and litter production in the scenarios}

The volume of growing stock and the amount of litter production drive the change in carbon stock of a forest. They develop according to Fig. 4 in the scenarios.

\section{Results}

\subsection{Change of the carbon stock of forest land}

The effects of the different harvest scenarios can be clearly seen in the changes in carbon stocks of trees, mineral soils, and peatland soils (see Fig. 5). In each pool, the carbon balance is the most positive in the LOW\&BIO- scenario, which is as expected. The lowest level of biomass removal yields the largest volume of growing stock and also produces a large amount of litter (Fig. 4), which feeds the soil carbon pool after 2020. Trees dominate the change in carbon stock of forests; the trees account for more than $80 \%$ of the total change in carbon stock.

The decline in the early years and the subsequent recovery of the sink in mineral soils is due to the high level of

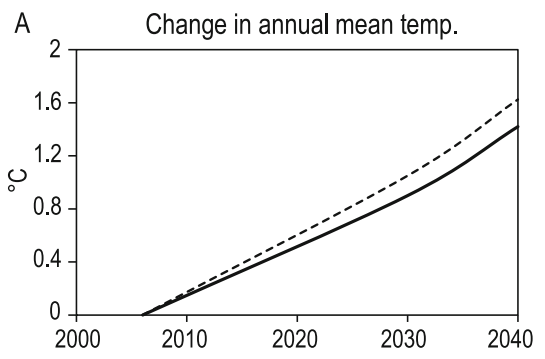

Fig. 3 Projected spatially averaged changes in annual mean a temperature and $\mathbf{b}$ precipitation under the A1B scenario, relative to year 2006 (Jylhä et al. 2009). The average for Southern Finland is denoted by a harvest in the 1990s. These harvests produced a large carbon stock in the soil, and this stock is still decomposing in the early 2010s. Only by around 2020 does the litter production from the increasing tree biomass match the decomposition. At the beginning of the simulation, the litter input is higher in the MOD\&BIO+ than in the LOW\&BIO- scenario (Fig. 4), and therefore, the sink of the mineral soils is likewise larger. After 2020, the increase in litter production from living trees in the LOW\&BIO- scenario reverses this situation.

Peatland soils emit carbon in all scenarios except in the last few years of the LOW\&BIO- scenario (Fig. 6). The emissions decrease in the LOW\&BIO- and MOD\&BIO+ scenarios as well as in the beginning of the POT scenario. The temporal development of the changes in carbon stock of peatland soils mirrors that of the litter production in all scenarios: the emissions decrease as long as the litter production increases (Fig. 4).

\subsection{Effect of fuelwood removal}

Fuelwood harvest affects the changes in carbon stock of forests in two ways: cutting living trees decreases the amount and growth of woody biomass, and the removal of residues decreases the litter input into the soil. The cutting residues affect only the carbon stock in the soil. We combined two levels of fuelwood removal (BIO- and $\mathrm{BIO}+$ ) with two levels of roundwood removal (LOW and MOD) (Table 1; see Fig. 6). After year 2020, the difference in the annual fuelwood removal between the $\mathrm{BIO}+$ and $\mathrm{BIO}-$ scenarios is $7.5 \mathrm{Mm}^{3}$ (Table 1). This translates to a difference of approximately $2.3 \mathrm{Tg}$ C/year and $2.7 \mathrm{Tg} \mathrm{C} /$ year in the change in carbon stock of forests after 2025 at both LOW and MOD levels of roundwood removal, respectively (Fig. 6). The change in tree stock accounts for most of this difference, $2.0 \mathrm{Tg} \mathrm{C} / \mathrm{year}$.

\subsection{Impact of climate change}

The effect of CC on all carbon pools is consistent across the LOW\&BIO- and MOD\&BIO+ scenarios; the forest carbon

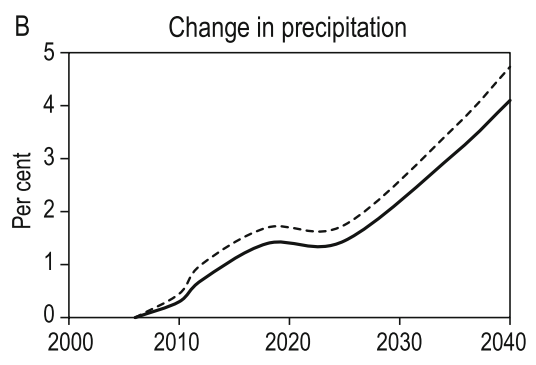

solid line and that of Northern Finland by a dashed line. Temperature changes are expressed in absolute terms and precipitation change as a percentage 
Fig. 4 Volume of growing stock (a) and annual litter production (b) in the scenarios (Table 1). CC (dashed line) indicates that the effect of climate change was included in simulation
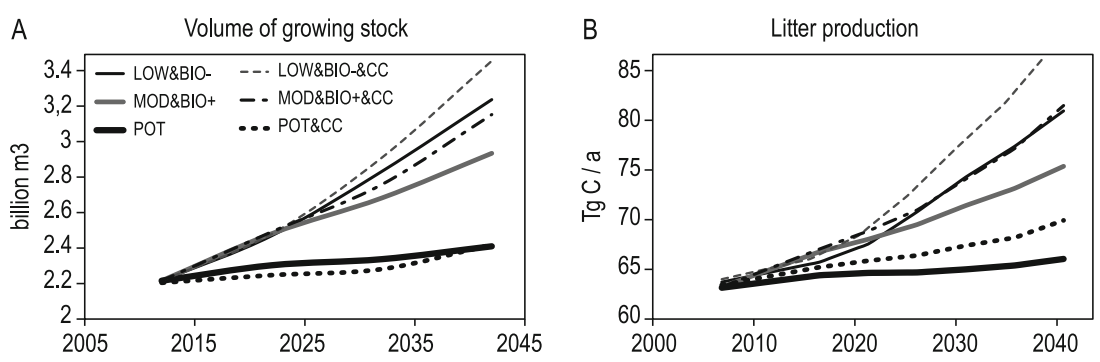

sink clearly increases (Fig. 7). The increase by 2042 is $38 \%$ and $58 \%$ in LOW\&BIO- and MOD\&BIO+ scenarios, respectively. The carbon stock of trees is the main cause of this increase because CC strongly promotes tree growth. The effect of CC on soil carbon pools is different than its effect on trees. On mineral soils, CC spurs decomposition faster than litter production at first and thus diminishes the sink before the year 2030. Only after 2030 does the increase in litter production of trees grow larger than the increase in the rate of decomposition. At that point, the effect of $\mathrm{CC}$ on the carbon stock of mineral soils turns positive in both scenarios. On peatland soils, CC tends to increase emissions. The increase in the rate of decomposition clearly exceeds the increase in the litter production by trees.

\section{Discussion}

Under the LOW\&BIO- and MOD\&BIO+ scenarios, forested land in Finland increasingly acts as a carbon sink. The tree growth exceeds removal in these scenarios. The reference level of forest management for Finland in the second commitment period of Kyoto protocol, 20.5 $\mathrm{Mt} \mathrm{CO}_{2}$ eq/year (5.58 Tg C/year), is clearly exceeded. In the scenario with the maximum sustainable amount of harvested wood (POT), the forest sink is marginal, and Finland fails to achieve its reference level.

In the Kyoto Protocol's first commitment period, Finland's assigned amount is $19.4 \mathrm{Tg} \mathrm{C} /$ year, of which the current forest sink of 9.49 Tg C/year (NIR2012) constitutes a large proportion. In the MOD\&BIO+ and LOW\&BIO $-\& C C$ scenarios, the forest sink will fall within the range of 13-29 Tg C/year in the year 2042 (Fig. 7). The assigned amount falls within this range. This shows that the forests can have an increasingly important role in the national GHG balance in the future. The active use of bioenergy (BIO+ vs. BIO-) diminishes the sink by $2.6 \mathrm{Tg} \mathrm{C} /$ year in the year 2042. A comparison of the LOW\&BIO- and MOD\&BIOscenarios (Fig. 6) shows that an increase of $12.7 \mathrm{Mm}^{3}$ in annual roundwood use (Table 1) diminishes the forest sink by $3.7 \mathrm{Tg} \mathrm{C} / \mathrm{year}$ in the year 2042. These values are small or moderate in comparison to the projected range of sink values, 14.6-21.4 Tg C/year in the year 2042 .

However, if carbon sequestered by forests would have a full monetary value as, for example, in the energy sector, the difference between the POT and LOW\&BIO- scenarios would be $€ 770$ million in 2042 (assuming a price of $€ 20$ per ton of $\mathrm{CO}_{2}$ ). From the point of view of $\mathrm{CC}$ mitigation, Finland should favor the LOW\&BIO- scenario that produces the maximum sink especially if we take into
Fig. 5 Change in the carbon stock of forest land (tree and soil pools combined) and separately for trees, mineral soils, and drained peatland soils in scenarios (Table 1) that represent different levels of wood use: low=LOW\&BIO-, moderate $=\mathrm{MOD} \& \mathrm{BIO}+$, high =POT; square markers show the values during 2000-2008 from Greenhouse Gas Inventory (Greenhouse gas emissions in Finland 19902010) (NIR2012). The effect of $\mathrm{CC}$ was not included
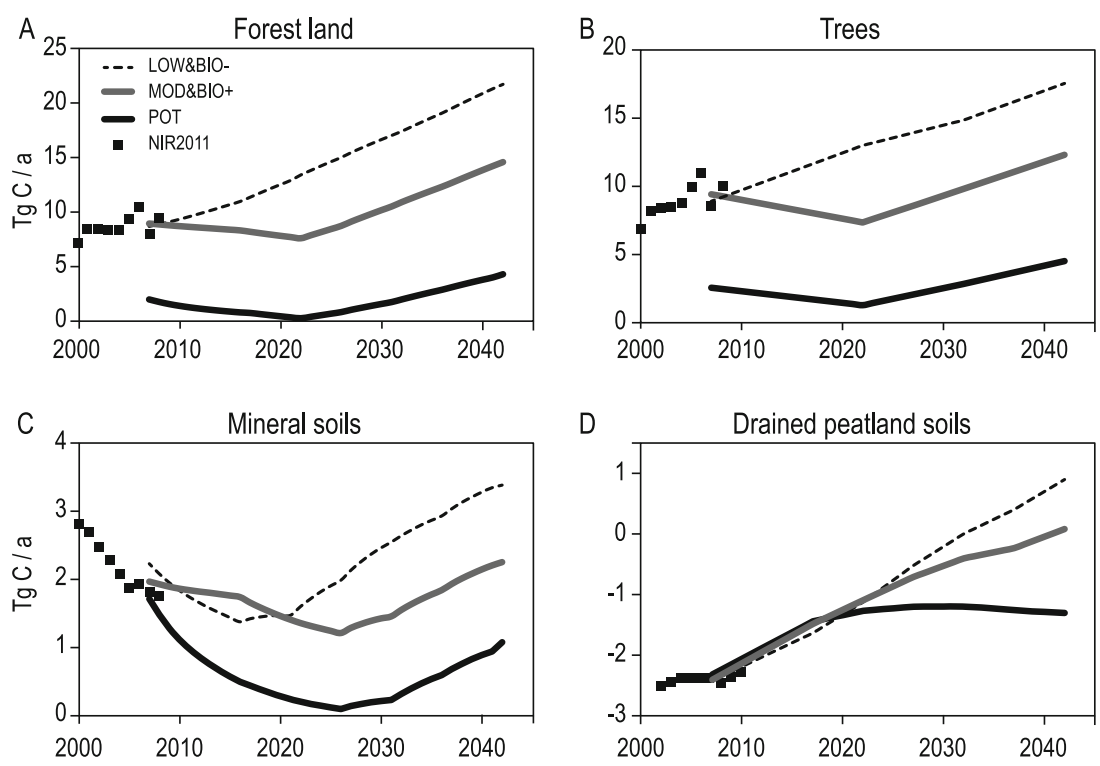

D

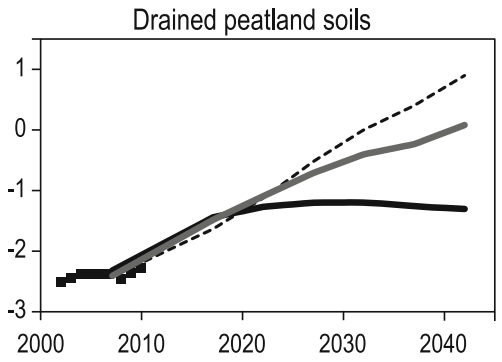


Fig. 6 The effect of fuelwood removal on carbon stocks of forest land (tree and soil pools combined) and separately for trees, mineral soils, and drained peatland soils. Solid lines denote fuelwood removal according to $\mathrm{BIO}-$ and dashed lines according to $\mathrm{BIO}+$ (Table 1). Two levels of roundwood removal (Table 1) are considered: LOW (thin line) and MOD (thick line). The effect of CC was not included
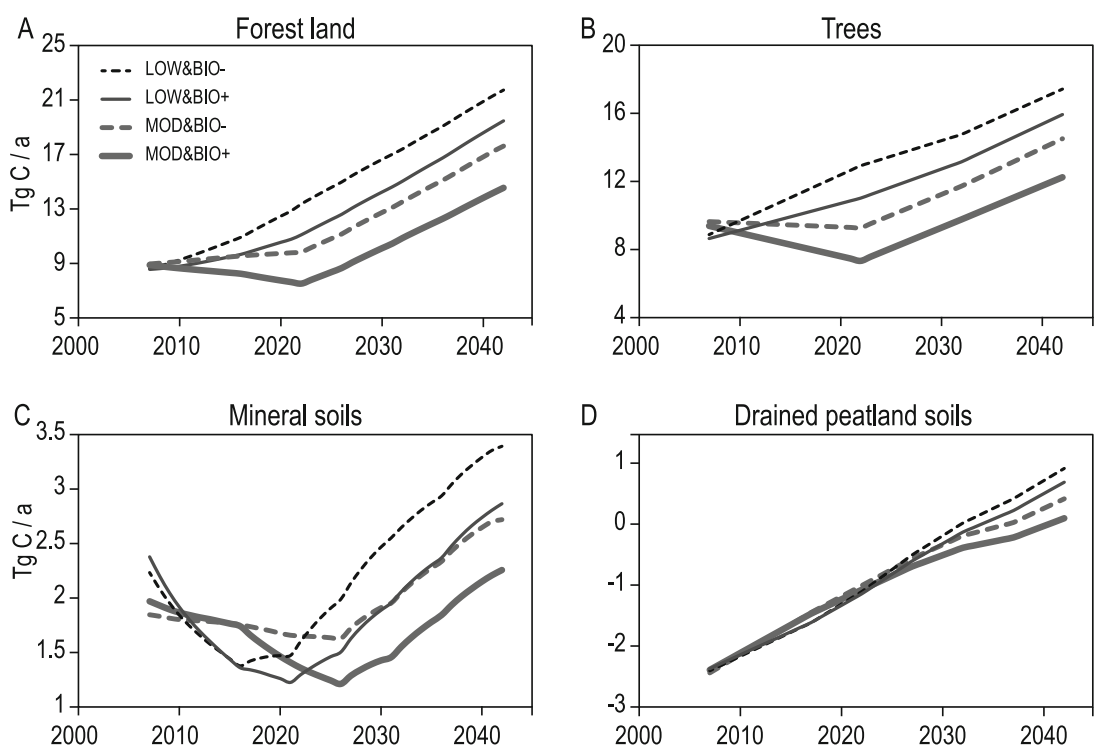

consideration that bioenergy may not be not carbon neutral (Schulze et al. 2012).

Böttcher et al. (2012) projected the forest sink of $24 \mathrm{EU}$ countries through 2030 by using two models of forest resources. They derived roundwood and fuelwood harvest from an economical model and from EU regulations. They considered two slightly different scenarios. The forest sink decreased in all cases. They attribute the result to the aging of the forests and to increased harvests. Our scenarios show an opposite trend (except POT). The MOD\&BIO+ scenario assumed a slight increase in the use of wood, but the forest sink increases even in that scenario. One explanation for the different trends is that the increase in wood use of Böttcher et al. (2012) was slightly higher. Another explanation is that the age structure of the Finnish forests is such that they can sustain a high rate of growth longer than the European forests on average.

The components of the change in carbon stock of forests (trees, mineral soils, and peatland soils) respond to harvest levels and $\mathrm{CC}$ differently. Increasing the harvest level of roundwood and bioenergy removal decreases the carbon sink of trees. The soils follow the trees in the long run (by the end of the simulation), but the short-term dynamics after the onset of the scenarios are different (Fig. 6). Harvest litter from large removals increases the carbon sink of mineral soils in comparison to the scenario of little removal. Only after approximately 15 years does the feedback through the tree stock (higher litter production from greater tree biomass) increase the carbon stock of mineral soils in the scenario with little removal.
Fig. 7 The effect of $\mathrm{CC}$ on the carbon stock of forest land (tree and soil pools combined) and separately for trees, mineral soils, and drained peatland soils in the scenarios defined in Table 1: low $=$ LOW\&BIO - and moderate $=$ MOD\&BIO + . Simulations including the influence of $\mathrm{CC}$ are indicated with dashed lines
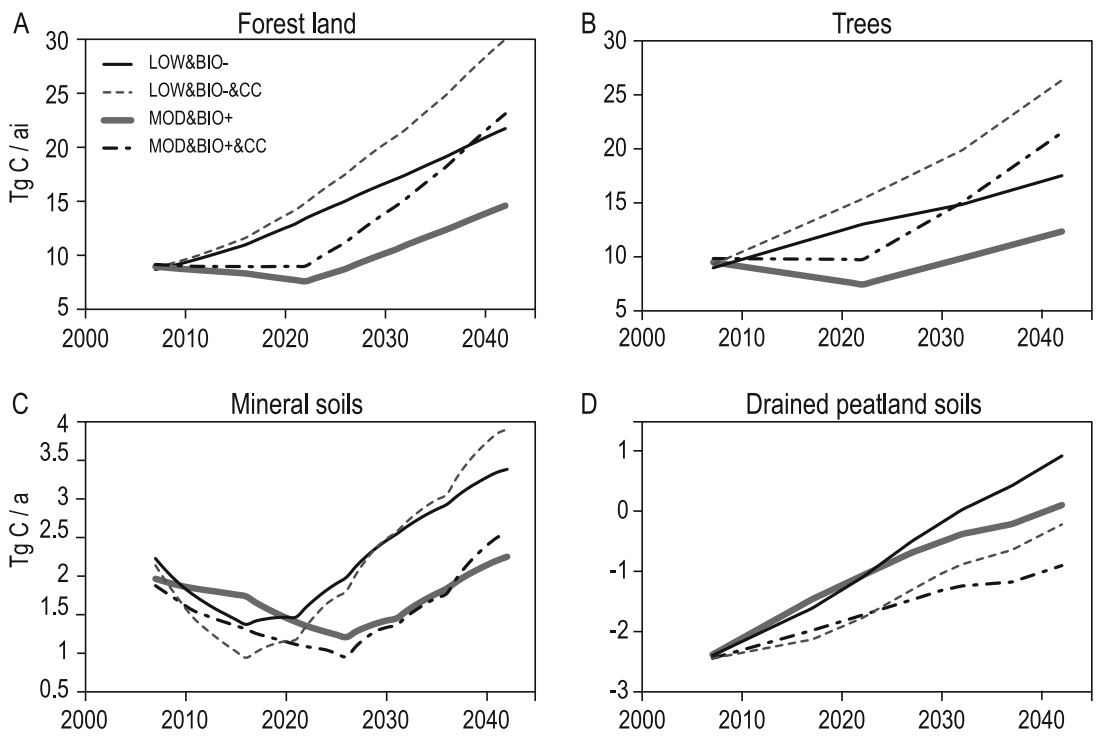

D

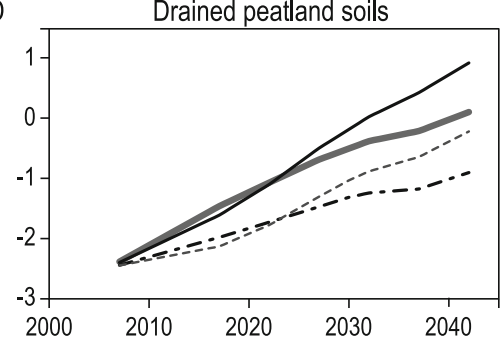


Including the effect of $\mathrm{CC}$ increases the forest carbon sink. The increase is $38 \%$ and $58 \%$ in 2042 under the LOW\&BIO- and MOD\&BIO+ scenarios, respectively. This is due to the increased tree growth that serves as a carbon sink and dominates the changes in carbon stock of forest land. Mineral soils clearly decline as a sink at the beginning of the simulation, and only after almost 30 years does the effect of CC lead to a slightly positive sink. The emissions from the drained peatland soils increase substantially under the effect of CC in all scenarios.

Matala et al. (2009) calculated that CC increased carbon stock of trees in Finland by $14 \%$ in year 2053 in comparison to the case without CC. They assumed that annual mean temperature increased $0.6{ }^{\circ} \mathrm{C}$ per decade. In our $\mathrm{CC}$ simulations, annual mean temperature increased $0.4{ }^{\circ} \mathrm{C}$ per decade and standing volume by $8 \%$ in year 2042 in comparison to the case without CC (Fig. 4a). This compares well to the result of Matala et al. (2009) since carbon stock of trees is proportional to their standing volume. Kellomäki et al. (2008) assessed that CC increases growth rate of forests in Finland by $29 \%$ in the period 2020-2050. In our simulations, the increase in the growth rate of trees due to $\mathrm{CC}$ in 2042 is $35 \%$ (not shown) that is comparable with the estimate of Kellomäki et al. (2008).

In our projections, many sources of uncertainty were inherent in the changes in carbon stocks resulting from wood use and the effects of CC. One less-well-known factor in the scenarios of roundwood demand is the amount of timber imports and exports. There were no studies available on timber trade scenarios, and the amounts of roundwood import are plausible values in these scenarios. Timber imports from Russia have varied annually by more than $10 \mathrm{Mm}^{3}$ in the last 10 years (Finnish Statistical Yearbook of Forestry 2011). If such future fluctuations were to occur in the timber trade, they would clearly affect domestic harvests in the range of $43.9-74.8 \mathrm{Mm}^{3}$ in the scenarios (Table 1). The $\mathrm{BIO}+$ scenario is based on implementation of the EU directive for the promotion of energy use from renewable sources by the Finnish government. The BIOscenario assumes a failure to reach the implementation targets and represents roughly the current level of bioenergy use. We tried to span the scenarios so that future roundwood and bioenergy demands would likely fall within their range. No numerical estimate for the uncertainty could be given.

The annual mean temperature is projected to be roughly $1.5{ }^{\circ} \mathrm{C}$ higher in 2040 than in 2007 in the CC scenario (Fig. 2a). It can be estimated (cf. Jylhä et al. 2009) that the uncertainty range of this value is between $1{ }^{\circ} \mathrm{C}$ and $2{ }^{\circ} \mathrm{C}$. In addition, the high $\mathrm{CO}_{2}$ concentration favors tree growth (Fig. 3a); hence, even without any temperature rise, tree growth is likely to increase. It is, therefore, quite safe to assume that $\mathrm{CC}$ increases the change in carbon stock of trees. One limitation of the method of using annual mean values is that the effects of litter on tree growth and decomposition are dependent on the timing of these events. If only winter temperature rises, it may have a minor effect, whereas an increase in spring and early summer temperatures evidently enhances growth and decomposition substantially.

One source of uncertainty may be related to the effects of climate warming on decomposition. In our models for decomposition (Yasso07 in mineral soils and emission coefficients in peatland forests), the decomposition of all soil carbon is assumed to be equally sensitive to changes in temperature. This is unlikely to be true (e.g., Davidson and Janssens 2006; Karhu et al. 2010). The temperature sensitivity of decomposition will increase in complicated and recalcitrant fractions of soil organic matter as long as some other factor prevents decomposition. One common preventive factor is bonding of soil organic matter to the soil mineral matrix. This can make the oldest soil organic matter less sensitive to temperature. For these reasons, decomposition may be remarkably more sensitive to temperature increase than future estimates in this study may indicate, especially when the response is dependent mostly on the unprotected temperature-sensitive fractions (Karhu et al. 2010). In the longer term, the oldest recalcitrant fractions may again make the stock of soil organic carbon tolerant of changes in temperature. Soil carbon models are currently being developed actively to account for these differences between the soil organic matter fractions, but the models are still not advanced enough to be used in these studies.

The uncertainties in the estimates of carbon stock changes are assessed in greenhouse gas inventories. The Finnish greenhouse gas inventory states that the relative uncertainties (twice the relative standard error) for carbon stock changes in trees, mineral soils, and drained peatland soils are $17.3 \%, 24.1 \%$, and $150.0 \%$, respectively (Greenhouse gas emissions in Finland 1990-2010). We estimated the changes in the carbon stocks of trees and soil, using roughly a similar method. In our case, an additional uncertainty in the values of the greenhouse gas inventory comes from scenarios (harvest levels and growth prediction). The above uncertainty values thus represent a lower limit of the actual uncertainty of our projections.

Acknowledgments Two anonymous referees are acknowledged for their suggestions that have significantly improved the paper.

Funding This study was funded by SETUILMU project "Greenhouse gas emission scenarios for agriculture, forestry and other land use". 


\section{References}

Böttcher H, Verkerk PJ, Gusti M, Havlík P, Grassi G (2012) Projection of the future $\mathrm{EU}$ forest $\mathrm{CO}_{2}$ sink as affected by recent bioenergy policies using two advanced forest management models. GCB Bioenergy. doi:10.1111/j.1757-1707.2011.01152.x

Cienciela E, Exnerova Z, Schelhaas M (2008) Development of forest carbon stock and wood production in the Czech Republic until 2060. Ann For Sci 65:603-612

Davidson EA, Janssens IA (2006) Temperature sensitivity of soil carbon decomposition and feedbacks to climate change. Nature 440:165-173

Finnish Statistical Yearbook of Forestry (2011) OSF. Agriculture, forestry and fishery. Finnish Forest Research Institute. http:// www.metla.fi/metinfo/tilasto/julkaisut/vsk/2011/index.html Accessed 31.1.2013

Greenhouse gas emissions in Finland 1990-2010 (2012) National inventory report to the UNFCCC and the Kyoto Protocol, 13 April 2012. Statistics Finland http://www.stat.fi/tup/khkinv/ unfccc nir 2012.pdf. Accessed 26.4.2012

Helmisaari $\mathrm{H}-\overline{\mathrm{S}}$, Hanssen K, Jacobson S, Kukkola M, Luiro J, Saarsalmi A, Tamminen P, Tveite B (2011) Logging residue removal after thinning in Nordic boreal forests: long-term impact on tree growth. For Ecol Manag 261:1919-1927

Hetemäki L, Hänninen R (2009) Arvio Suomen puunjalostuksen tuotannosta ja puunkäytöstä vuosina 2015 ja 2020. Metlan työraportteja 122. (in Finnish) www.metla.fi/julkaisut/ workingpapers/2009/mwp122.htm. Accessed 31.1.2013

Hynynen J, Ojansuu R, Hökkä H, Supilehto J, Salminen H, Haapala P (2002) Models for predicting stand development in MELA System. The Finnish Forest Research Institute, Research Papers 835:116

Jylhä K, Ruosteenoja K, Räisänen J, Venäläinen A, Tuomenvirta H, Ruokolainen L, Saku S, Seitola T (2009) Arvioita Suomen muuttuvasta ilmastosta sopeutumistutkimuksia varten. ACCLIMhankkeen loppuraportti. Finnish Meteorological Institute, Reports 2009:4 (in Finnish with an English summary)

Kärhä K, Elo J, Lahtinen P, Räsänen T, Keskinen S, Saijonmaa P, Heiskanen H, Strandström M, Pajuoja H (2010) Kiinteiden puupolttoaineiden saatavuus ja käyttö Suomessa vuonna 2020. Työ- ja elinkeinomisteriön julkaisuja: Energia ja ilmasto 66/ 2010. Työ- ja elinkeinoministeriö. 68 p. ISBN 978-952-227468-7, ISSN 1797-3562. (in Finnish)

Karhu K, Fritze H, Hämäläinen K, Vanhala P, Jugner H, Oinonen M, Sonninen E, Tuomi M, Spetz P, Kitunen V, Liski J (2010) Temperature sensitivity of soil carbon fractions in boreal forest soil. Ecology 91:370-376

Karjalainen T, Pussinen A, Liski J, Nabuurs G-J, Erhard M, Eggers T, Sonntag M, Mohren GMJ (2002) An approach towards an estimate of the impact of forest management and climate change on the European forest sector carbon budget: Germany as a case study. For Ecol Manag 162:87-103

Kellomäki S, Peltola H, Nuutinen T, Korhonen KT, Strandman H (2008) Sensitivity of managed boreal forests in Finland to climate change, with implications for adaptive management. Phil Trans R Soc B 363:2341-2351. doi:10.1098/rstb.2007.2204

Kirschbaum MUF (1995) The temperature dependence of soil organic matter decomposition, and the effect of global warming on soil organic C storage. Soil Biol Biochem 27:753-760

Lappi, J (1992) JLP a linear programming package for management planning. The Finnish Forest Research Institute, Research Papers 414. http://mela2.metla.fi/mela/j/manuals/jlp.pdf

Liski J, Lehtonen A, Palosuo T, Peltoniemi M, Eggers T, Muukkonen P, Mäkipää R (2006) Carbon accumulation in Finland's forests 1922-2004 - an estimate obtained by combination of forest inventory data with modelling of biomass, litter and soil. Ann For Sci 63:687-697

Matala J, Ojansuu R, Peltola H, Sievänen R, Kellomäki S (2005) Introducing effects of temperature and $\mathrm{CO}_{2}$ elevation on tree growth into a statistical growth and yield model. Ecol Modell 181:173-190

Matala J, Kärkkäinen L, Härkönen K, Kellomäki S, Nuutinen T (2009) Carbon sequestration in the growing stock of trees in Finland under different cutting and climate scenarios. Eur J For Res 128:493-504

Ministry of Employment and the Economy (2010) Suomen kansallinen toimintasuunnitelma uusiutuvista lähteistä olevan energian edistämisestä annetun direktiivin 2009/28/EY mukaisesti. (in Finnish) http://www.tem.fi/files/29773/Suomen_kansallinen_ toimintasuunnitelma.pdf Accessed 31.1.2013

Minkkinen K, Laine J, Shurpali N, Mäkiranta P, Alm J, Penttilä T (2007) Heterotrophic soil respiration in forestry-drained peatlands. Boreal Env Res 12:115-126

Nuutinen T, Matala J, Hirvelä H, Härkönen K, Peltola H, Väisänen H, Kellomäki S (2006) Regionally optimized forest management under changing climate. Clim Change 79:315-333

Ojanen P, Minkkinen K, Alm J, Penttilä T (2010) Soil-atmosphere $\mathrm{CO}_{2}, \mathrm{CH}_{4}$ and $\mathrm{N}_{2} \mathrm{O}$ fluxes in boreal forestry-drained peatlands. For Ecol Manag 260:411-421

Ojanen P, Minkkinen K, Penttilä T (2013) The current greenhouse gas impact of forestry-drained boreal peatlands. For Ecol Manag 289:201-208. doi:10.1016/j.foreco.2012.10.008.\&lt

Peckham SD, Gower ST, Buongiorno J (2012) Estimating the carbon budget and maximizing future carbon uptake for a temperate forest region in the U.S. Carbon Balance Manag 7:6 doi:10.1186/1750-0680-7-6

Pingoud K, Lehtilä A (1997) Role of forest sector and bioenergy in limiting the carbon emissions in Finland. Biomass Bioenergy 13:413-420

Poudel BC, Sathre R, Gustavsson L, Bergh J, Lundström A, Hyvönen $R$ (2011) Effects of climate change on biomass production and substitution in north-central Sweden. Biomass Bioenergy 35:4340-4355

Poudel BC, Sathre R, Bergh J, Gustavsson L, Lundström A, Hyvönen $R$ (2012) Potential effects of intensive forestry on biomass production and total carbon balance in north-central Sweden. Environ Sci Pol 15:106-124

Rantakari M, Lehtonen A, Linkosalo T, Tuomi M, Tamminen P, Heikkinen J, Liski J, Mäkipää R, Ilvesniemi H, Sievänen R (2012) Yasso07 soil carbon model — testing against repeated soil carbon inventory. For Ecol Manag 286:137-147

Redsven V, Hirvelä H, Härkönen K, Salminen O, Siitonen M (2011) MELA2009 Reference Manual (2nd edition). Finnish Forest Research. 664 p. ISBN 978-951-40-2283-3

Repola J (2009) Biomass equations for Scots pine and Norway spruce in Finland. Silva Fennica 43:625-647

Repola J (2008) Biomass equations for birch in Finland. Silva Fennica 42:605-624

Salminen O, Hirvelä H (2008) MELA-vaihtoehtolaskelmat kansallisen metsäohjelman 2015 valmistelua varten. In: Uusivuori, J., Kallio, M. and Salminen, O. (eds.), Vaihtoehtolaskelmat Kansallisen metsäohjelman 2015 valmistelua varten. (in Finnish) http:// www.metla.fi/julkaisut/workingpapers/2008/mwp075.htm Accessed 31.1.2013

Schulze ED, Körner C, Law B, Habrl H, Luyssaert S (2012) Largescale bioenergy from additional harvest of forest biomass is neither sustainable nor greenhouse gas neutral. GCB Bioenergy 4:611-616

Siitonen M, Härkönen K, Hirvelä H, Jämsä J, Kilpeläinen H, Salminen O, Teuri M (1996) MELA handbook 1996 edition. The Finnish Forest Research Institute, Research papers 622 
Thürig E, Kaufmann E (2010) Increasing carbon sinks through forest management: a model-based comparison for Switzerland with its Eastern Plateau and Eastern Alps. Eur J For Res 129:563-572

Tuomi M, Thum T, Järvinen H, Fronzek S, Berg B, Harmon M, Trofymow JA, Sevanto S, Liski J (2009) Leaf litter decomposition - estimates of global variability based on Yasso07 model. Ecol Modell 220:3362-3371
Tuomi M, Laiho R, Repo A, Liski J (2011) Wood decomposition model for boreal forests. Ecol Modell 222:709-718

Turunen J (2008) Development of Finnish peatland area and carbon storage 1950-2000. Boreal Env Res 13:319-334

Werner F, Taverna R, Hofer P, Thürig E, Kaufmann E (2010) National and global greenhouse gas dynamics of different forest management and wood use scenarios: a model-based assessment. Environ Sci Pol 13:72-85 